\title{
VISUAL METHODS IN ENGINEER AND TEACHER EDUCATION IN SCIENCE - CONFERENCE REPORT
}

The International Conference on Visual Methods in Engineer and Teacher Education in Science was held in Sopron, Hungary, 21-23 October, 2014, in the organization of the Hungarian Society for Geometry and Graphics, with the help of the University of West Hungary. The conference was realized through the generous support of the International Visegrad Fund's Small Grant No. 11420082.

This event brought together some 30 scientists from the Visegrad countries (Slovakia, Poland, Czech Republic and Hungary) discussing educational and scientific aspects of visual methods. From the applications of GeoGebra in secondary schools through spatial abiltites and their improvements to spline surfaces several topics were presented by the participants. Fruitful discussions during and after the programme certainly brought people and ideas together. Future plans, such as extending collaboration in the field and the establishment of a repository for teaching materials applying visual methods are among the results of the conference. Some scientific contributions of the conference may come into published form in the near future.

In the name of the Organizers: Miklós Hoffmann (Department of Mathematics, Eszterházy Károly College, Eger, Hungary, hofi@ektf.hu)

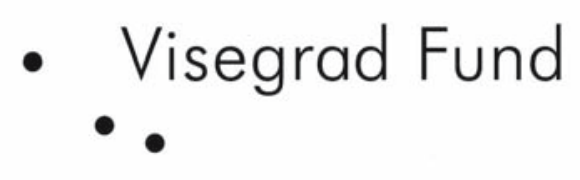

